\title{
РЕЛИГИОЗНИ ЕЛЕМЕНТИ В ТУРСКАТА ПОЕЗИЯ СЛЕД ТАНЗИМАТА
}

\author{
Вежди Хасан \\ RELIGIOUS ELEMENTS IN TURKISH POETRY AFTER THE TANZIMAT \\ Vezhdi Hasan
}

\begin{abstract}
Turkish poets turn to religious topics immediately after converting to Islam. The orientation towards Western literature led to the adoption of the poetic forms. Society's worldview changed. After the Tanzimat, the religious elements continued to be present in Turkish literature, but through the prizm of social relations in Turkish society. The authors found inspiration in the religious images in the holy books. Both their hardships and their personal virtues were described. The poets emphasized their determination and steadfastness in the name of good. They set personal examples of modesty, tolerance, strength and self-sacrifice. Through the religious images, poets sent messages to the modern people.
\end{abstract}

Key words: Turkish literature, religious elements, poetry

DOI: https://doi.org/10.46687/JHDS5061

Религиозните образи заемат особено място в турската литература както преди, така и след Танзимата ${ }^{1}$. В поезията срещаме имената на пророци и светци като Адем (Адам) ${ }^{2}$, Хабил (Авел), Муса (Мойсей), Исхак (Исаак), Юсуф (Йосиф), Давуд (Давид), Ибрахим (Авраам), Нух (Ной), Иса (Исус), Муса (Мойсей), Нух (Ной), Сюлейман (Соломон), Юсуф (Йосиф), Мухаммед, Али и др. (Тӧkel 2000: 99-100). Освен че те са вдъхновение за поети и писатели, чрез религиозните образи се проследява и историята на човечеството. Най-често срещан е образът на Адем (Адам). Този интерес може да се обясни и с желанието на хората да научат повече за възникването на живота на планетата. Авторите описват с подробности живота на първите хора Адем (Адам) и Хава (Ева) в рая, а

\footnotetext{
${ }^{1}$ Танзиматьт, чието началото се поставя с прочитането на Гюлханския хатишериф на 3 ноември1839 г. в парка Гюлхане, се свързва с обществени реформи в Османската империя, започва с въвеждане на пакет от закони, обнародвани от султан Абдул Меджид (1839-1861) при встъпването му на престола. Завършва с приемането на първата османска конституция през 1876 г. Танзиматът поставя началото на модернизация и европеизация на държавата. Социално-икономическите и културните промени, които характеризират прехода към модерната епоха, оказват сериозно влияние върху всички сфери на турското общество. Танзиматьт поставя и начало на новата турска литература.

2 В скоби са посочени имената, с които са известни в Библията.
} 
после и на Земята. Те са изпратени на земята след неспазване на божията забрана. Според християнската религия това е първородният грях и хората се раждат грешници (Paz 1996: 24). В турската поезия Адем е известен като баща на човечеството (на турски Ebü'l Beşer) и като чистото създание на Всевишния (на турски Safiyyullah). Той е създаден от пръст (кал). Името му означава човек (на турски $\hat{d} d e m$ ), както и нищета (на турски adem) (Pala 1989: 6-7). В суфизма ${ }^{3}$ едно от висшите стьпала на духовното извисяване е факир (нищета), разбиран като освобождаване от привързаността към материалното и създаване на висша пустота, готова да поеме Откровението. В този смисъл висшата пустота е ценна колкото ськровищата на Балха ${ }^{4}$ (Chalakova, Hasan 2008: 220). В стихотворението си „Ябълка I“, Салих Зеки Актай пише:

Преди да се види светлина в бездната на хаоса, Преди от вечен сън да се събуди мрака, Защото божествената светлина оцвети земята, Създаде осем рая около своя трон, По клоните на туба ${ }^{5}$ се появиха всички плодове, Състрадателният Аллах разреши на Адем, Каза: вземи от всеки плод, от всеки клон (Aktay 1932: 108).

В стихотворението „, Човечество “ Джахит Съткъ Таранджъ пише, че грехът привлича хората. Според него човекът предпочита земните приключения пред вечното щастие в рая. В този смисъл ябълковото

\footnotetext{
${ }^{3}$ Суфизмът или тасаууф е течение в исляма, стремящо се към разкриването на негови скрити мистични измерения. Последователите на суфизма се наричат суфии или дервиши. Класическите суфистки учители дефинират суфизма като „учение, чиято цел е поправянето на сърцето и отвръщането му от всичко друго, освен от Аллах Теаля“ $<$ https://bg.wikipedia.org/wiki/\%D0\%A1\%D1\%83\%D1\%84\%D0\%B8\%D0\%B7\%D1\%8A\% D0\%BC (status 11.11.2021)>. Суфийската поезия е направление в старата турска литература.

${ }^{4}$ Султанът на Балха - Едхем (Хазрат Ибрахим бен Адхам), починал между 875 и 880 г., първоначално живее в невероятен разкош, но се отказва от короната си на цар и става дервиш. Известна е следната притча за него: Веднъж са се карали два дервиша. Ибрахим казал: „Вие нищо не сте платили за да живеете в нищета. Тъй като сте получили това право безплатно - иенете го”. Един от дервишите ехидно отговорил: „А ти да не би да си платил висока цена за да станеш дервиш?" Ибрахим спокойно го погледна и каза: „Да в замяна на това аз дадох иарството Балха, но смятам, че платих малка цена за правото да се наричам дервиш. В сравнение с ичарството, това е много ценно нещо, братко”.

${ }^{5}$ Туба е дърво в Рая, клоните на което са надолу, а корените - нагоре.
} 


\section{Годишник на ФХH, XXXII A}

дърво е символ на удоволствията и желанието за живот. Както Адем и Хава, въпреки всички предупреждения, са откъснали ябълката и са извършили грях, така и съвременният човек иска да живее без ограничения и е склонен да върши грехове:

Вярно е, че съм потомък на Адем и Хава;

Влюбих се в ябълковия клон.

Все още помня дъжда от потопа.

Благодарен съм, че достигнах до сала на Нух.

Ако е писано да умра някой ден,

Светлината в очите, труда, потта на челото,

Добрите и лошите дни, които съм преживял

Не бих ги заменил за приказките за рая (Tarancı 1946: 45).

В стихотворението „,Труден преход“, поетът Бехчет Неджатигил пише за трудностите в живота, започнали още с появата на първия човек:

Времето се върти около Адем и Хава.

Светът е вечен с мъжа и жената,

Но, това което наричат живот,

От ден на ден става все по-труден (Necatigil 1983: 557).

В стихотворението „Ръие “ на Фарук Нафиз Чамлъбел се говори за греха и благочестието, които символизират ръцете. Има препратки към житията на религиозните образи. От една страна, в този поетически текст се говори за ръката на Зюлейха, разкъсала ризата на Юсуф, а от друга страна, за изцеляващата ръка на Иса, рьката на Муса, прокарваща път през морето, и ръката на Мухаммед, извличаща вода от пустинята. Хава е подмамена от дявола да откъсне забранения плод:

Натъжи ни този грях, трябва възмездие

Подмамвайки я да докосне забранения плод

Превърна в ад земята за Адем, рьката на Хава (Çamlıbel 2012: 187).

В стихотворението „Острови от ивветя “ поетът предрича, че след всяка раздяла предстои ново сближаване:

Да се срути всеки ден по един свят в далечината.

Намерили отново рая Адем и Хава (Çamlıbel 2012: 50). 
Според Айхан Кьрдар алчността на хората води началото си от Адем и Хава. Те не се примиряват с това, което им е дадено, а искат и всичко останало. По този начин вредят на самите себе си. Поетьт смята, че алчността е в основата на повечето злини:

Омесени сме с ревност жълта,

Омесени сме с алчност червена,

Омесени сме със страх черен,

Адем и Хава поставиха началото на греха (Kurdar 1961: 12).

За поети като Бекир Съткъ Ердоган Адам и Ева символизират любовта. В стихотворението „Пътища“, поетьт пише:

Знам за път, който води към Адем и Хава,

Знам за път, който води към любовта и обичта.

Един път, който, преминавайки през градините на живота

С годините, с мъката, води до отвъдното (Erdoğan 1965: 32).

Юсуф Зия Ортач също се спира на начина, по който Хава е подмамена от дявола. Дявольт символизира егото, а човекът е подвластен на своето его. Същевременно описва и любовта на Адем и Хава:

Дяволе, подмамил даже Адем и Хава,

Дяволе, изхвърлил на земята Адем и Хава от небесата.

Сега Адем стене на далечен остров.

Едно време беше в рая той.

Хава, Хава, кажи ми бързо къде си?

Трепти гласът ти в разбитата ми душа!

Да бях вихьр да отвея душите,

Хава!... Хава!... Ако можех да те зърна!

Лека полека ще ме убие тази мъка (Ortaç 1919: 18).

B периода на националната литература ${ }^{6}$ поети като Якуп Кадри също вмъкват елементи от житията на религиозни образи. Поетът е вдъхновен от притчата за Адем и Хава:

${ }^{6}$ Националната литература се развива между 1911 и 1923 г. Представителите ѝ се стремят да изчистят езика от чуждиците, да наложат силабическото стихосложение и да се насочат към проблемите на обикновения човек. 


\title{
Годишник на ФХH, XXXII A
}

Тази първа рана за душите ни въпреки всичко вечно ли ще ни боли? След този ден извършихме хиляди грехове; хиляди като Хава бяха ръка за ръка с хиляди дяволи; изядоха хиляди плодове, на нито една наказанието ѝ не продължи толкова дълго. С какво тази земя се отличава от рая? (Karaosmanoğlu 1970: 27).

\section{В стихотворението „От лозята на светщ̧ите“ Якуп Кадри описва няколко религиозни личности:}

\author{
Скъпи приятелю, толкова ми се гади, \\ сякаш съм изпил кръвта на Хабил. \\ Спря ми дъха, сякаш плувам в Потопа, \\ сякаш лежа болен в постелята на Еюб. \\ Изморен съм, \\ сякаш години наред съм вървял след Муса. \\ Безпомощен съм, \\ сякаш се моля заедно с Исхак. \\ Толкова съм наранен, \\ сякаш съм разпънат на кръста вместо Иса. \\ Във всяка точка на тялото ми \\ и във всеки ьгъл на душата ми има следи от нещастие. \\ Но всички те са породени от първоначалното нещастие. \\ В кръвта има живот, в Потопа - сила, в мълниите - сила, \\ о Боже! \\ Какъв е смисълът да се доближа до Хава, \\ да се освободя от дявола \\ и да властвам над всички живи същества? \\ Ако съм далеч от тебе? (Karaosmanoğlu 1970:28).
}

В турската литература Муса (Мойсей) присъства както в поезията, така и в прозата. Той е източник на вдъхновение за поетите, които растат в атмосфера на мистицизъм. Затова поетите се интересуват от живота му и неговите чудеса. В свещените книги и в религиозните текстове Муса се споменава като пророк, който Всевишният изпраща на израилтяните. Той е един от пророците, споменати и в Корана. Поради тази причина се счита за свещен в ислямската вяра и култура. Образът на Муса вдъхновява мистични емоции:

Муса и магьосниците се изправиха един срещу друг.

Израел и Египет се изправиха един срещу друг.

Червено море се разтегна като кожа на елен.

В дървото имаше живот, макар и да беше изсьхнало.

Съживи го ръката на Муса

И дървото победи живака. 
Вярата победи познанието (Karakoç 2010: 239).

В турската поезия Иса (Исус) е представен като пророк, който лекува болните, кара слепите да прогледнат и съживява мъртвите (Pala 1989: 248-249). Според исляма Всевишният не е роден, няма деца и няма равен на него. Адем (Адам) също няма баща, нито пък майка. Затова и Иса не е син на Всевишния. В Корана и хадисите ${ }^{7}$ се споменава като Иса (Исус), син на Мерйем (Мария) (Y1ldırım 1991: 20). В стихотворението „Ръие“ “ Фарук Нафиз Чамлъбел описва изцелителната сила на Иса:

Молитвите му помагат на неподвижния да стане,

С докосване с ръце отваря очите на слепец (Çamlıbel 2012: 51).

Много автори се спират на притчата за Юсуф ${ }^{8}$ и Зюлейха. Зюлейха е дъщеря на султана на Магреб ${ }^{9}$. Тя се влюбва в египетски царедворец, който се появява в сънищата ѝ. След този сън Зюлейха решава да се ожени за него без да го е виждала. Всъщност това е позицията, която Юсуф ще получи в бъдеще, а Зюлейха, без да знае това, се омъжва за Потифар. Юсуф е син на Якуб ${ }^{10}$ и Рахил. Той е любимото дете на Якуб и това предизвиква завист у братята му. Те решават да се отьрват от него. Пускат го в кладенец и се връщат при баща си с окървавената му риза. Обясняват му, че е разкъсан от вълк. Междувременно пред кладенеца

\footnotetext{
7 Хадис е устно предание за пророка Мухаммед. Колекциите от Хадиси са важни за определянето на Суната (или ислямския начин на живот) от традиционните ислямски школи $<$ https://bg.wikipedia.org/wiki/Хадис (status 10.11.2021)>.

${ }^{8}$ Става въпрос за Йосиф - единадесетият син на Яков, който служи в Египетското царство в периода между 1900 - 1600 г. пр. Хр. Там тълкува сънищата на фараона. Владетелят му е благодарен, че е спасил народа от глад и го назначава за свой пръв помощник. Настъпва голям глад и в страната на Юсуф. Баща му изпраща синовете си в Египет, за да закупят зърно. Така те се срещат с Юсуф. Фараонът изпраща богати дарове на Якуб и го кани да се пресели в неговото царство с целия си род $<$ https://bg.wikipedia.org/wiki/Йосиф_(Библия (status 01.10.2021)>.

${ }_{9}^{9}$ Магреб е област от Африка, разположена на север от Сахара и на запад от Нил. В найтесен смисъл съвпада с района на Атласките планини. От геополитическа гледна точка се счита, че областта включва Мароко, Западна Сахара, Алжир, Тунис, понякога Либия и рядко Мавритания <https://bg.wikipedia.org/wiki/Магреб (status 01.10.2021)>).

10 Яков (или Иаков, изписвано в синодалния превод на Библията) е третият от библейските патриарси, по-малък брат на Исав. Преданието разказва, че при раждането си се е хванал за петата на своя брат, за да излезе от майчината утроба (производно от „акев“" - пета̀). Според Библията името Яков означава „който прави засада”

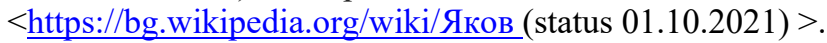




\section{Годииник на ФХН, XXXII A}

спира керван. Търговците решават да напоят камилите и откриват момчето. Братята му виждат, че той е изваден от кладенеца и решават да им го продадат. Така попада в Египет. Търговците препродават момчето на Потифар. Юсуф спечелва доверието му и става управител в неговия дворец. Зюлейха се опитва да съблазни младежа, но той, воден от вярата си и уважението към господаря, отказва да се сближи със съпругата му. Разгневената египтянка, въпреки цялата си борба, не може да получи Юсуф и без колебание го обвинява в непристойни действия. Юсуф е хвърлен в затвора (Çetin 2000: 113-114). Макар и да го обича толкова много, го оставя да гние в тъмницата. В този момент се наблюдава инстинкт за самозащита, който се превръща в гняв и отмъщение (Türkdoğan 2008: 103). От една страна, Зюлейха показва смелост и се бори за постигане на целта си, а от друга страна, плаче и стене, жертвайки се за безнадеждната любов, което е типично за любовните истории на Изтока (Türkdoğan 2008: 103). В годините, когато Юсуф е затворен, тя прекарва времето си в сълзи и губи красотата си. Раздава богатството си на тези, които носят новини от Юсуф. След като загубва всичко, остава сама и никой не се сеща за нея. Дори смъртта я заобикаля. Престава да контактува с външния свят и мисли само за Юсуф. Губи всичко материално и се отдава на духовното. Легендата за Юсуф и Зюлейха е едно от върховите постижения в древната литература и затова много автори от по-късни периоди се връщат към тази тема.

В стихотворението „Юсуфовци““ Фарук Нафиз Чамлъбел възвеличава осъдените по политически причини и ги сравнява с Юсуф. Според поета те споделят неговата съдба, защото са осъдени несправедливо:

\footnotetext{
Нощем в тъмницата юсуфовци лежат наредени.

От прежълтелите им лица разчитам съня им.

Някои са седнали на стол, а други са разпънати на кръст

И търсят своя свят в тъмницата (Çamlıbel 1969: 181).
}

В стихотворението „Ръие““ Фарук Нафиз Чамлъбел, описвайки ролята на ръцете в човешкия организъм, се спира на притчата за Юсуф и Зюлейха. Според него ръцете са много полезни, но могат да вършат и лоши неща. Поетът описва ръцете на Зюлейха, която съвсем незаслужено обвинява Юсуф:

Да бяха забравили Юсуф десетте му братя във водата, Да бяха свършили мъките му в кладенеца, 


\section{Вежди Хасан. Религиозни елементи...}

При пътуването на кервана от пустинята за Египет, Да не беше се превърнал този ден в трон за Юсуф.

Четиридесет века си спомняме за едно:

Срама от разкъсването на ризата на Юсуф,

Отгоре до долу разкри ръката на Зюлейха (Çamlıbel 1969: 72).

Ариф Нихат Ася описва любовта си към любимата като се опира на любовта на Зюлейха към Юсуф. В стихотворението любимата му е красива като Юсуф, а той е влюбен като Зюлейха:

Виждам нов свят при всяко нейно идване...

Угасва светлината около мен и все още виждам...

Има промисъл в това, че я наричам Юсуф,

В сънищата си се виждам като Зюлейха (Asya 1976: 53).

В друго свое стихотворение Ариф Нихат Ася предава страданието си чрез преданията за Юсуф и Зюлейха и Лейла и Меджнун:

Юсуф спи в черната пръст без Зюлейха;

Меджнун спи в пустинния пясък без Лейла;

Бъди благодарен, че си в прегръдките на богатството.

Адем спи в пустошта без Хава (Asya 1976: 83).

Джемал Сюрея описва трудностите в своя живот, съпоставяйки ги със съдбата на Юсуф:

Родих се и отворих очи в един товарен вагон

И Юсуф, който се грижеше за зърното на фараона,

С разкъсаната си отзад риза

Напомняше на птица с прекършени крила (Süreyуa 1973: 38).

Бехчет Неджатигил свързва изхвърлянето на Юсуф в кладенеца с раздялата. В стихотворението си „Раздяла” описва трудностите в живота на двама влюбени:

Керваните си тръгнаха,

Юсуф е в кладенеца.

Събужда се и спи, и пъшка

В градината на Юсуф.

Опря се на клона и охка.

Керваните си тръгнаха.

Докога ще е раздялата?

Младежът е в хотелска стая. 


\section{Годишник на ФХH, XXXII A}

Седи, разхожда се и плаче.

Девойката е при своята майка.

Гледа огледалото и плаче.

Докога ще е раздялата? (Necatigil 1944: 11).

Описвайки трудностите в живота, Орхан Вели се спира на необходимостта от справедливо разпределение на благата и посочва за пример Юсуф:

Дял и за нас от брашното, дял и за нас.

Идете, жито раздава Юсуф.

Дял и за нас от брашното, дял и за нас

Преди да дойде слънчевото затъмнение (Veli 1973: 23).

Поетът Джошкун Ертепънар, представител на крьга Хисар ${ }^{11}$ в новата турска литература, набляга на невинността на Юсуф и на мъката на неговия баща. В исляма Юсуф е символ на несправедливото обвинение:

Да знаеш е хубаво,

Да знаеш е и страшно..

Знаех за братята на Юсуф, които го хвърлиха в кладенеца.

Знаех за сълзите на Юсуф...

Знаех за мъките на Иса заради вярата (Ertepınar 1969: 27).

Представителите на Второто ново ${ }^{12}$ черпят вдъхновение от суфизма и обръщат поглед към поезията и философията на личности като Мевляна Джеляледдин Руми ${ }^{13}$ и Юнус Емре ${ }^{14}$. Сезаи Каракоч споделя: „Ще възродим Анадола така, както го е правил Мевляна след опустошенията на кръстоносците, нахлули от запад и монголите - от изток. “В стихотворението „Възраждане“ пише:

${ }^{11}$ Крьгът Хисар се появява през 50-те години на XX век. Представителите му смятат, че поезията трябва да е независима от идеологии и да приема новостите.

12 Второто ново е течение в новата турска литература. Появява се през 50-те години на $\mathrm{XX}$ в. Представителите му използват сложни символи в поезията, наблягат на описанията. Вдъхновяват се от дадаизма и сюрреализма.

${ }^{13}$ Мевляна Джеляледдин Руми е великият ислямски мистик, поет и проповедник, живял през XIII в. Проповядва толерантност към всички хора без значение на вяра, етнос и paca.

${ }^{14}$ Юнус Емре е известен турски суфист, живял през XIII в. Стиховете му са посветени на любовта към човека и природата. 


\section{Вежди Хасан. Религиозни елементи...}

Според това, което ме научи мама,

Аллах е по-близо до мен от моята аорта.

Мама ме научи какво е роза ${ }^{15}$.

Розата е потта от слънцето на Неговата безгранична доброта.

Мама тайно плачеше, произнасяйки името на Юнус.

Дьрветата плачеха, небето потъмняваше, слънце и луна са в плен.

Баща ми, подготвяйки се за битки в дългите зимни нощи,

Качил се на бял кон, идваше Али ${ }^{16}$ (Fuat 1994: 529).

Хазрети Али присъства и в много други произведения. В текста на турския епос „Кьороглу” пише: „Али ще се качи на трона. Сълзите в очите изведнъж ще секнат. Али този ден е твоят ден “. Влиянието на исляма се проявява във всички версии на епоса (Chufadar 2019: 90-91).

Убеден, че поезията трябва да отразява историята, културата и бита на дадена нация, Едип Джансевер смята, че поетьт трябва да е и добър психолог, да познава в детайли естетиката на обществото и да усеща динамиката на нейното развитие. Според него е необходимо в стихотворенията да присъстват типични за езика изрази и словосъчетания, които да обогатят поезията (Cansever 2000: 71-72). Едип Джансевер, също като останалите представители на Второто ново, използва религиозни елементи, за да подсили въздействието на стиховете:

Боже, за нея една люлка!

Камък, за да не спре камъка!

За да не замръзне в празнотата,

Боже, за нея една люлка!

Да ходи в празнотата и да се връща... (Cansever 2011: 105).

Без сьмнение, централно място сред религиозните образи в турската литература е образът на пророка Мухаммед. В турската литература се набляга на добродетелите, на които учи последователите си. Много често е наричан „Любимият на Аллах“ (на турски: Habibullah). В старата турска литература са писани жития за пророка (на турски: Siyer-

\footnotetext{
${ }^{15}$ В исляма розата е символ на пророка Мухаммед.

${ }^{16}$ Али е племенник на пророка Мухаммед и съпруг на дъщеря му Фатима. Известен е със своята смелост.
} 
i Nebi), а по-късно и мевлиди ${ }^{17}$ (Çelebioğlu 1998: 356-357). Всеки етап от живота му е описан в отделни литературни произведения. Едно от найоригиналните сред тези произведения е „Раждането на пророка“ (Mevlid-iNebi). В него се описват раждането, животът и смъртта на пророка. По повод нощта на раждането поетът Мехмет Акиф Ерсой възхвалява пророка Мухаммед в две свои стихотворения, написани през 1910 и 1911 г. В тях Мехмет Акиф отправя и послание към последователите на пророка.

Ей, нощ, да беше продьлжила да съществуваш.

Да беше превърнала деня в светлина (Ersoy 1910).

В стихотворението „Една нощз“ Ерсой пише, че роденият преди четиринадесет века пророк на четиридесет години е получил просветление. Дошъл е да спаси човечеството от самоунищожение. Изградил е нов ред, основаващ се на толерантно съжителство между хората. Пророкът е описан като борец срещу несправедливостта и закрилник на онеправданите.

Четиринадесет века минаха, ей, нощ!

Роди светлина от небесата, нали?

...

Боже, това сираче, плаващо в полята ти, е като бисер.

Никога да не се чувства сираче... Амин (Ersoy 1911).

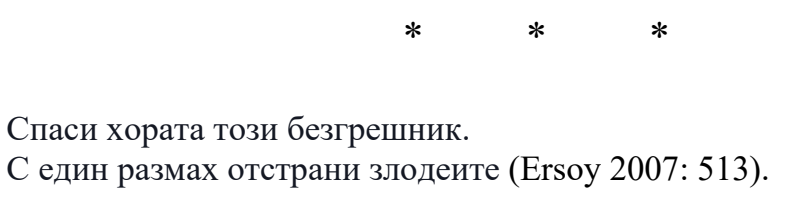

Мехмет Акиф иска обществото да се отьрси от негативното и да поеме по нов път, по пътя на прогреса. Той отправя молитви към Всевишния да спаси човечеството от деградацията и разрухата:

\footnotetext{
17 „Мевлид“ означава „рождение”. Нощта на рождението на пророка Мухаммед Расулюллах „саллялаху алейхи ве селлем” се нарича мевлид-кандил (кандил = нощ). Това е нощта между 11-я и 12-я ден на месец реби'ул-еввел. След нощта кадр това е следващата най-ценна нощ в исляма <www.ehlisunnetbg.com/statii/mawlid/ (status 12.10.2021)>.
} 


\section{Вежди Хасан. Религиозни елементи...}

Не оставяй Исляма самотен!

Не оставяй Исляма безпомощен (Ersoy 2007: 244).

В стиховете на Неджип Фазъл Късакюрек пророкът Мухаммед е представен като символ на единението и пример за подражание. Той е на мнение, че редът, въведен от пророка, трябва да се разпространи в найчистата си форма. Повечето от стиховете му на религиозна тематика са събрани в стихосбирката „Мъка“:

В тебе е човекът и обществото, в тебе е основата и сградата.

Повярвахме в това, което си ни донесъл и си ни научил (Kısakürek 2015: 79).

Поетьт Сезаи Каракоч пише, че пророкът Мухаммед е освободил хората от невежеството. Спасил ги е от насилието. Пророкът трябва да е пътеводна светлина за младото поколение (Karakoç 2015: 418). Затова са описани и неговите възможности:

Той е извора, в който е изчистена ризата на Юсуф.

Вратите на Египет се отварят чрез него.

Той разтопява желязото на Давуд.

Той говори чрез мравката (Karakoç 2010: 188-189).

Поетьт споменава останалите пратеници и в други свои стихотворения:

Дойде и Муса.

Бяха изписани мраморни плочи.

Дойде и Ибрахим.

Около него беше огнен обръч.

...

Дойде и Юсуф.

Вдясно от него бе Бюнямин.

Дойде и Сюлейман.

Извести ни една древна мравка.

Дойде и Давуд.

Разчу се навсякъде (Karakoç 2010: 262).

В турската поезия Сюлейман (Соломон) е символ на чудотворна сила и власт. Той е повелител на демони, а тронът му се носи от ветровете. Сюлейман е пророк и владетел. Посветен е в тайните науки и притежава свръхестествени възможности. Владее езиците на всички животни и общува с тях. Според Корана той е син на Давуд (Давид). 


\section{Годишник на ФХН, XXXII A}

Смята се, че е живял между IX и X век пр. н. е. и е царувал повече от четиридесет години (Onay 2004: 445). Поетите се придържат към описанията му в Корана. Описва се неговият трон, споменава се за разговорите му с мравки, с диви животни и хищни птици (Levend 1984: 120). Поетът Айхан Кърдар се спира на неговите свръхестествени възможности:

Събуди се, Велики Сюлейман!

Събуди се!

Научи ме на езика на птиците и вълците (Kirdar 1961: 27).

Танзиматът е свързан с политически и социално-икономическите промени в Османската държава и внася промени в културата и изкуството. Турското общество се ориентира към западния начин на живот, което оказва влияние и на турската литература. Появяват се нови жанрове. Западното влияние получава силен тласък след обявяването на страната за република. Турските поети продължават да вмъкват религиозни елементи в стиховете си. Те се опират на житията на религиозните личности, описани в свещените книги. Много често се споменава за Адем и Хава (Адам и Ева). Поетите ги свързват с първородния грях и с идеята, че човечеството е обречено да страда. Това усещане се подсилва и от притчата за Кабил и Хабил (Каин и Авел), където Кабил убива своя брат. Всъщност това е първото братоубийство. В поезията са вплетени и много други образи - Сюлейман (Соломон), Юсуф (Йосиф), Давуд (Давид), Муса (Мойсей), Ибрахим (Аврам), Нух (Ной) и др. Сред тях централно място заема образът на пророка Мухаммед. Изтъквайки достойнствата на религиозните личности, поетите наблягат на ценностите, които те изповядват. По този начин те отправят послание към съвременниците си за изграждане на толерантно и състрадателно общество. Чрез своята скромност, милосърдие и саможертва религиозните личности са пример за духовно усъвършенстване.

\section{ИЗПОЛЗВАНА ЛИТЕРАТУРА}

Aktay 1932: Aktay, S. Z. Asya Şarkıları. İstanbul: Sühulet Kütüphanesi.

Asya 1976: Asya, A. N. Rubaiyyat-1 Arif'II. İstanbul.

Chalakova, Hasan 2008: Chalakova, T., V. Hasan. Metafora v edin ot gazelite na Nefi. Payazhina na smisala. - In: Godishnik na Shumenskiya universitet „Episkop Konstantin Preslavski“. Fakultet po humanitarni nauki. T. XIXA. Shumen: UI „Episkop Konstantin Preslavski“, s. 197-223 [Чалъкова, Т., В. 
Хасан. Метафора в един от газелите на Нефи. Паяжина на смисъла. - В: Годишник на Шуменския университет. Факултет по хуманитарни науки. Т. ХІХА. Шумен: УИ „Епископ Константин Преславски“, с. 197-223].

Cansever 2000: Cansever, E. „Edip Cansever'le Konuştum“, Gül Dönüyor Avucumda, İstanbul: Adam Yayınc1lik.

Cansever 2011: Cansever, E. Sonrası Kalır, İstanbul: Yapı Kredi Yayınları.

Chamlıbel 1959: Çamlıbel, F. N. „Eller“, Heyecan ve Sükun, İstanbul: İnkılap Kitabevi.

Chamlıbel 1969: Çamlıbel, F. N. Han Duvarları, İstanbul.

Chamlıbel 2012: Çamlıbel, F. N. Han Duvarları / Toplu Şiirler. İstanbul: Yapı Kredi Yayınları.

Chelebioğlu 1998: Çelebioğlu, A. Türk Edebiyatında Manzum Dinî Eserler, Eski Türk Edebiyatı Araştırmaları, İstanbul.

Chetin 2000: Çetin, N. Yeni Türk Şairinin „Yusuf ve Züleyha Hikâyesi“ Duyarlığı. Türkoloji Dergisi. 109-143.

Chufadar 2019: Chufadar, N. Fantastichnite elementi v destanite za Kyoroglu. Shumen: UI „Episkop Konstantin Preslavski“, 192 s. [Чуфадар, H. Фантастичните елементи в дестаните за Кьороглу. Шумен: Университетско издателство „Епископ Константин Преславски“, 192 с.].

Erdoğan 1965: Erdoğan, B. S. Dostlar Başına, İstanbul.

Ersoy 1910: Ersoy, M. A. „Leyle-i Mevlidü’n-Nebî Aleyhisselâm“, Sirât-1 Müstakîm, Cilt: 4, Sayı: 81, 12 Rebiülevvel 328 (24 Mart 1910).

Ersoy 1911: Ersoy, M. A. "Leyle-i Mevlidü'n-Nebî Sallallahu Aleyhi ve Sellem", Sirât-1 Müstakîm, Cilt: 6, Sayı: 132, 14 Rebîülevvel (16 Mart 1911).

Ersoy 2007: Ersoy, M. A. Safahat, İstanbul: Dergah Yayınları.

Ertepınar 1969: Ertepınar, C. „Öğrensin İnsanoğlu”, Güzel Dünya. Ankara.

Fuat 1994: Fuat, M. Çağdaş Türk Şiiri Antolojisi, İstanbul: Adam Yayıncılık.

Karakoç 2010: Karakoç, S. Gün Doğmadan, İstanbul: Diriliş Yayınları.

Karakoç 2015: Karakoç, S. Günlük Yazılar II - Sütun, İstanbul: Diriliş Yayınları.

Karaosmanoğlu 1970: Karaosmanoğlu, Y. K. Erenlerin Bağından, İstanbul: Milli Eğitim Basımevi.

Kurdar 1961: Kırdar, A. Lo, İstanbul: Baha Matbaas1.

Kısakürek 2015: Kısakürek, N. F. Çile, İstanbul: Büyük Doğu Yayınları.

Naci 2003: Naci, F. Reşat Nuri'nin Romancılığı, İstanbul: Yap1 Kredi Yayınları.

Necatigil 1944: Necatigil, B. Değirmen, İkinci Kânun, İstanbul.

Necatigil 1983: Necatigil, B. Düz Yazılar, İstanbul: Cem Yayınevi.

Levend 1984: Levend, A. S. Divan Edebiyatı Kelimeler, Remizler, Mazmunlar, Mefhumlar. İstanbul: Enderun Kitapevi.

Onay 2004: Onay, A. T. Eski Türk Edebiyatında Mazmunlar, İstanbul: MEB Yayınları.

Onur 1991: Onur, M. N. Yusuf u Züleyhâ, Ankara: Akçağ Yayınları. 
Pala 1989: Pala, İ. Ansiklopedik Divan Şiirleri Sözlüğü, C 2, Ankara: Kültür Bakanlığı Yayınları.

Paz 1996: Paz, O. Çamurdan Doğanlar, İstanbul: Can Yayınları.

Süreyya 1973: Süreyya, C. „Kişne Kirazını ve Göç, Mevsim", Beni Öp Sonra Doğur Beni, İstanbul.

Tarancı 1946: Tarancı, C. S. Otuzbeş Yaş, Varlık Yayınları. Istanbul.

Tökel2000: Tökel, D. A. Divan Şiirinde Mitolojik Unsurlar Şahıslar Mitolojisi, Ankara: Akçă̆ Yayınları.

Türkdoğan 2008: Türkdoğan, M. Klasik Türk Edebiyatında Yusuf u Züleyha Mesnevileri Üzerine Mukayeseli Bir Çalışma, Erzurum: Atatürk Üniversitesi Sosyal Bilimler Enstitüsü, Doktora Tezi.

Veli 1973: Veli, O. „Buğday“, Bütün Şiirleri, 12. basılış, İstanbul.

\section{Електронни ресурси}

$<$ www.ehlisunnetbg.com/statii/mawlid/(status 15.06.2021)>

$<$ https://bg.wikipedia.org/wiki/Магреб (status 05.06.2021) $>$

$<$ https://bg.wikipedia.org/wiki/Яков (status 20.06.2021) $>$

$<$ https://bg.wikipedia.org/wiki/Хадис (status 06.07.2021>

$<$ https://bg.wikipedia.org/wiki/Йосиф_Библия (status 20.06.2021) $>$

$<$ https://bg.wikipedia.org/wiki/\%D0\%A $1 \% \mathrm{D} 1 \% 83 \% \mathrm{D} 1 \% 84 \% \mathrm{D} 0 \% \mathrm{~B} 8 \% \mathrm{D} 0 \% \mathrm{~B} 7 \% \mathrm{D}$

$1 \% 8 \mathrm{~A} \% \mathrm{D} 0 \% \mathrm{BC}$ (status 20.06.2021)> 